\title{
Erratum to: Proline-Rich Hypothalamic Polypeptide Has Opposite Effects on the Proliferation of Human Normal Bone Marrow Stromal Cells and Human Giant-cell Tumour Stromal Cells
}

\author{
R. K. Chailakhyan - Yu. V. Gerasimov \\ M. R. Chailakhyan · Armen A. Galoyan
}

Published online: 19 March 2010

(C) Springer Science+Business Media, LLC 2010

Erratum to: Neurochem Res

DOI 10.1007/s11064-009-0113-7

Unfortunately in the original version of this article the last author name was not included.

The correct author group is as given below:

R. K. Chailakhyan, Yu. V. Gerasimov, M. R. Chailakhyan, Armen A. Galoyan

The online version of the original article can be found under doi:10.1007/s11064-009-0113-7.

R. K. Chailakhyan $(\bowtie) \cdot$ Yu. V. Gerasimov •

M. R. Chailakhyan

Gamaleya Research Institute of Epidemiology and

Microbiology, Russian Academy of Medical Sciences,

Gamaleya Str., 18, 123098 Moscow, Russian Federation

e-mail: info@riem.ru; rubenchail@yandex.ru
A. A. Galoyan
H. Buniatian Institute of Biochemistry, NAS RA, 5/1 Sevag Str.,
375014 Yerevan, Republic of Armenia 